\title{
A review of the effects of metallic nanoparticles on fish
}

\author{
Hana Čaloudová, Jana Čaloudová, Zdeňka Svobodová \\ University of Veterinary Sciences Brno, Faculty of Veterinary Hygiene and Ecology, \\ Department of Animal Protection and Welfare and Public Veterinary Medicine, Brno, Czech Republic
}

Received January 16, 2021

Accepted August 31, 2021

\begin{abstract}
Many important discoveries have been made in the field of nanotechnology in the last 40 years. Since then, nanoparticles became nearly ubiquitous. With their spreading use, safety concerns have warranted extensive research of nanotoxicity. This paper offers information about the occurrence, transport, and behaviour of metallic nanoparticles in the aquatic environment. It further summarizes details about parameters that dictate the toxicity of nanoparticles and discusses the general/common mechanisms of their toxicity. This review also focuses on fish exposure to nanoparticles, including the possibility of trophic transport through the food chain. Information on some of the most frequently used metallic nanoparticles, such as silver, gold, and titanium dioxide, is further elaborated on.
\end{abstract}

Toxicity, environment, silver, gold, titanium dioxide

The dawn of nanoscience and nanotechnology is connected to the invention of the Scanning Tunneling Microscope (STM) in 1981, which allowed scientists to observe individual atoms for the first time (Binnig et al. 1982). Since then, breakthrough discoveries have been made in almost every scientific field, including physics, chemistry, biology, engineering, or medicine. The basic definition states that nanoparticles (NPs) are particles of a size between 1 and $100 \mathrm{~nm}$ (ISO 2011). The size range is restricted arbitrarily, there is no clear cutoff in the properties of particles at $100 \mathrm{~nm}$ (Geertsma et al. 2015). Moreover, NPs are usually not entirely round, homogenous, unbound particles. Those aspects are taken into consideration by the Commission Recommendation on the definition of nanomaterial (2011/696/EU) which states that nanoparticles are not only particles in an unbound state but also aggregates or agglomerates where for $50 \%$ or more of the particles in the number size distribution, one or more external dimensions are in the size range of $1-100 \mathrm{~nm}$. In specific cases, this threshold can even be lowered to $1 \%$.

This might seem like a completely new area of materials that humans have never encountered, but the opposite is true. Nanoparticles were contained in a colloidal solution called "soluble gold" which was used for medicinal purposes more than 2000 years ago. During the Roman Empire and later in the Middle Ages, Au and Ag NPs were used to stain coloured glass (Horikoshi and Serpone 2013). Furthermore, NPs are not only humanmade but also arise from natural processes, such as the photobiogeochemical reaction leading to the formation of Ag NPs in the aqueous environment by reducing silver ions with organic matter (Hou et al. 2013). Nanoparticles are also formed during combustion and are present as ultra-fine particles in the atmosphere. They are also formed by cells as products of bacterial metabolism. Due to this long-term presence of nanomaterials in ecosystems, it can be assumed that biological systems have established mechanisms at the level of cells and organisms to deal with their presence (Monteiro-Riviere and Tran 2007).

Address for correspondence:

Hana Čaloudová

Department of Animal Protection and Welfare and Public Veterinary Medicine

Faculty of Veterinary Hygiene and Ecology

University of Veterinary Sciences Brno

Palackého tř́ida 1946/1, 61242 Brno, Czech Republic

Telephone: +420541562788

E-mail: H17345@vfu.cz

http://actavet.vfu.cz 
Yet, the ever-widening range of products and applications of NPs is associated with the increasing frequency and quantity of their unintentional release into the environment. The release may occur at all stages: during the manufacturing, use, and disposal of NPs-containing products. This brings uncertainty about possible environmental and health risks, especially in relation to substances such as metals that are a well-known current threat to the environment (Kovářík et al. 2020; Svoboda et al. 2020). Currently, metallic NPs represent the second largest market share of all NPs with an estimated value of 16 billion USD in the year 2020, and is projected to more than double the market value by 2027 , growing at a compound anual growth rate of $14.2 \%$. The highest growth is predicted for the pharmaceutical and healthcare sector, followed by electrotechnology and catalyst sectors (Global Industry Analysts, Inc. 2020; Grand View Research, Inc. 2020). Therefore, this review further focuses predominantly on metallic NPs.

\section{Classification of metallic NPs}

Metallic NPs can be divided into four categories based on their composition. The first group are pure metal-based NPs, usually comprised of noble metals (Ag, $\mathrm{Au}, \mathrm{Pt}$, etc), the second group are metal oxide NPs, which can have magnetic $\left(\mathrm{Fe}_{3} \mathrm{O}_{4}, \mathrm{Fe}_{2} \mathrm{O}_{3}\right.$, etc) or semiconductor properties $\left(\mathrm{TiO}_{2}, \mathrm{ZnO}\right.$, etc). The third group are chalcogenide NPs, represented by sulphides, selenides, and tellurides ( $\mathrm{PbS}, \mathrm{ZnSe}, \mathrm{CdTe})$. The fourth group are doped metal/metal oxide/metal NPs, which combine beneficial properties of both metals (Zn-Ag, Pt-Ni, etc) (Khanna et al. 2019; Yaqoob et al. 2020).

\section{The occurrence of metallic NPs in the aquatic environment}

The exact volumes of metallic NPs in the environment are not known; only estimates of the environmental concentrations of certain NPs are available. Currently, research is focused on the use of NPs in pesticides, fertilizers, and water and soil remediation products, which could be a significant source of contamination in the future. Mainly carbon NPs, metals, and their oxides are investigated (Khot et al. 2012).

The aquatic environment can be contaminated by the direct entry of NPs into water (for example during remediation, leaching of NPs during the use of the products, or accidental leaks), through emissions from wastewater treatment plants, air deposition, and flushings from contaminated soil (Gottschalk et al. 2009; Impellitteri et al. 2013; Gottschalk et al. 2015). Landfills are especially significant sources of contamination of ecosystems (Gottschalk et al. 2015).

Wastewater treatment plants can remove a significant part of NPs, for example, $97 \%$ of Ag NPs are removed from the water column into sewage sludge (Impellitteri et al. 2013). The methods of handling the sewage sludge differ among countries, in some places, they can be applied to the soil for their beneficial high contents of organic matter (Kwak and An 2016).

Application of sewage sludge can be hazardous due to high predicted concentrations of NPs, ranging in hundreds to thousands of $\mathrm{mg} \cdot \mathrm{kg}^{-1}$ for $\mathrm{TiO}_{2} \mathrm{NPs}$, tens of $\mathrm{mg} \cdot \mathrm{kg}^{-1}$ for $\mathrm{ZnO}$ NPs, and dozens of $\mu \mathrm{g} \cdot \mathrm{kg}^{-1}$ for Ag NPs (Gottschalk et al. 2009; Sun et al. 2014; Gottschalk et al. 2015; Sun et al. 2016). According to the predictive models, European surface waters contain tens to thousands of $n g \cdot l^{-1}$ of TiO $\mathrm{NPs}$, tens to hundreds of $\mathrm{ng} \cdot \mathrm{l}^{-1}$ of $\mathrm{ZnO}$ NPs, and units to tens of $\mathrm{ng} \cdot \mathrm{l}^{-1}$ of Ag NPs (Gottschalk et al. 2009; Sun et al. 2014; Gottschalk et al. 2015; Sun et al. 2016; Peters et al. 2018).

\section{Behaviour and stability of metallic NPs in the aquatic environment}

Metallic NPs are not fully soluble in water and therefore models valid for soluble chemicals cannot be used to assess their behavior and toxicity. Instead of dissolving, we 
have to take into consideration the formation of stabilized suspensions. Most metallic NPs are hydrophilic and often have low solubility, which can be perceived positively because metal ions tend to be their most toxic form (Batley et al. 2013). An example is the silver ion $\mathrm{Ag}^{+}$, which is more toxic than silver bound in the form of compounds and $\mathrm{Ag}^{0}$ within NPs (Hogstrand and Wood 1998; Ribeiro et al. 2014). The fate of dissolved ions is influenced by the composition of the environment, $\mathrm{Ag}^{+}$in natural waters rapidly forms sulphides and chlorides, which are insoluble, have lower toxicity, and are deposited in sediments (Kaegi et al. 2013). Sedimentation is another important way of loss of NPs from the water column. It is usually preceded by particle aggregation, the extent of which depends on $\mathrm{pH}$, the presence of cations, ionic strength, and the size, shape, and charge of particles (Batley et al. 2013; Schaumann et al. 2015). The sea and brackish regions have high ionic strength, so lower concentrations of NPs can be expected due to rapid aggregation in those environments (Pamies et al. 2014; Li et al. 2016).

Both homoaggregation (NPs form aggregates with each other) can occur, or more often heteroaggregation, when they bind to naturally occurring colloids, which are present in waters in significant concentrations, namely $1-10 \mathrm{mg} \cdot \mathrm{l}^{-1}$. These colloids consist of inorganic (e.g. metal oxides and sulphides, amorphous silicon), organic (formed primarily by humic substances and fibrous material, which may be polysaccharides and proteins formed by microorganisms), and biological components (viruses, bacteria). The fibrous material facilitates the aggregation of NPs, while humic substances can stabilize the dispersion of NPs by creating a coating that stabilizes the charge of the particle (Batley et al. 2013; Kaegi et al. 2013). Nanoparticles can also undergo redox reactions that change the chemical properties of the particle surface and can affect its environmental behaviour.This is typical for $\mathrm{Fe}^{0}$ which is used for water remediation. Iron particles oxidize rapidly in the environment, reducing the pollutant, such as trichloroethylene (Liu et al. 2005).

\section{Determining properties of metallic nanoparticles}

The toxicity of metallic NPs is dictated by multiple parameters, which must be taken into consideration as a complex of information, that includes their chemical composition, crystal structure, and purity of the sample, method of synthesis, size, and surface area of the nanoparticle (Warheit 2008; Wijnhoven et al. 2009) Larger particles are usually found to be less toxic, due to a smaller surface area. At the same volume, they have fewer atoms in the surface layer available for interaction with other compounds or ionization (Angel et al. 2013). At the same time, the nanosize provides opportunity to cross biological barriers and cell membranes (Nel et al. 2006). A study by Lee et al. (2007) demonstrates the passage of Ag NPs with Brownian diffusion through the chorion pore canals into the chorionic space and inner mass of zebrafish (Danio rerio) embryos in vivo. Ivask et al. (2014) show the size- and concentration-dependent effects of citrate-coated Ag NPs $(10 \mathrm{~nm}, 20 \mathrm{~nm}, 60 \mathrm{~nm}$, and $80 \mathrm{~nm})$ on bacteria, yeast, algae, crustaceans, and mammalian cells in vitro. The shape of the particle plays an important role, as well. Hua et al. (2014) found that exposure of zebrafish embryos to $\mathrm{ZnO}$ nanosticks had more serious effects on the survival rate and hatching of the embryos than $\mathrm{ZnO}$ nanospheres or cuboidal submicron particles. Another aspect is surface chemistry, such as their ability to form reactive species, catalytic and photocatalytic activity, leading to reactive oxygen species (ROS) production when irradiated by ultraviolet rays, as has been described for $\mathrm{TiO}_{2}$ and $\mathrm{ZnO}$ particles (Clemente et al. 2013; Sharma et al. 2020; Valério et al. 2020). The presence of coatings and addition of functional groups to the NPs surface alter their surface properties, improve their overall function, biocompatibility, or dispersion in aquatic media or reduce photocatalytic ROS production (Warheit 2008). For example, polyvinylpyrrolidone 
(PVP) coating of Au NPs is considered safer and more biocompatible than citrate coating (Zhou et al. 2009; Iswarya et al. 2016).

This information must be considered in relation to the characteristics of the exposure media $(\mathrm{pH}$, presence of ions, and ligands, as mentioned above) which in reality differ greatly for in vitro and in vivo settings. The precise particle and exposure characterization is a key factor of each experiment ( $\mathrm{Nel}$ et al. 2006; Warheit 2008; Wijnhoven et al. 2009).

\section{Toxicodynamics of metallic nanoparticles in fish}

There are several distinct toxic mechanisms by which NPs can impact aquatic organisms, which often act together and lead to similar results.

The most significant mechanism is the excessive production of ROS, overwhelming the cell antioxidant mechanisms, which can cause oxidative stress, leading to protein destabilization, lipoperoxidation of the cell membrane, DNA damage, causing genotoxic effects and cell death (Nel et al. 2006; Manke et al. 2013; Fu et al. 2014; Fard et al. 2015).

In many of the metallic NPs, the release of ions is a significant cause of adverse effects. The cytotoxic action of metal ions is caused by the complexation of metal cations with thiol groups of proteins and enzymes, which causes their inactivation (Sevcikova et al. 2011). Thiol groups are present in enzymes responsible for dealing with oxidative stress, such as lactate dehydrogenase and glutathione, which complicates the distinction of the two above mentioned toxicological mechanisms, when the enzyme activity is measured (Ulrich and Jakob 2019). In the case of silver ions, there is also a more pronounced specific toxicological mechanism in fish. Specific inhibition of $\mathrm{Na}^{+} / \mathrm{K}^{+}$-ATPase leading to blockage of active uptake of $\mathrm{Na}^{+}$and $\mathrm{Cl}^{-}$on gill basolateral cells, leading to disruption of osmoregulation and death (Morgan et al. 1997; Hogstrand and Wood 1998). However, Yue et al. (2016) show, that the inhibition of $\mathrm{Na}^{+} / \mathrm{K}^{+}$-ATPase was caused by both $\mathrm{AgNO}_{3}$ and particulate $\mathrm{Ag}$ NPs (dissolution rate of $\mathrm{Ag}^{+}$was $2.37 \%$, thus ions can be only accounted for $16 \%$ of observed effect).

The mechanical effect is often attributed to particles with a greater aggregation rate. In fish, the adhesion of NPs to the gills and a subsequential mechanical restriction of gas exchange was described by Ma and Lin (2013). In fish embryos, aggregation of NPs on a surface of the chorion can block the chorion pore canals and cause hypoxia, which manifests with a decreased hatching rate (Shih et al. 2016; Caloudova et al. 2018).

Due to the larger surface area, small dimensions, and high sorption capacity, NPs can also act as a Trojan horse, binding contaminants to their surface, transporting them into organisms, where they can be released (Deng et al. 2017). This effect was reported by Zhu et al. (2011) in Haliotis sp. embryos exposed to tributyltin, and coexposed to $\mathrm{TiO}_{2} \mathrm{NPs}$ and tributyltin. While the $\mathrm{TiO}_{2} \mathrm{NPs}$ alone had no negative developmental effect at $2 \mathrm{mg} \cdot \mathrm{l}^{-1}$, the same concentration increased the toxicity of tributyltin 20-fold, causing a drop in the hatching rate and an increase in the presence of malformations compared to exposition of embryos to tributyltin only.

In the case of metallic nanoparticles with antimicrobial properties, such as $\mathrm{ZnO} N P s, \mathrm{TiO}_{2}$ NPs or Ag NPs, the adverse effect on the diversity and composition of the microbiome of the fish should be taken into consideration (Azizi-Lalabadi et al. 2019; Chupani et al. 2019).

\section{Toxicokinetics of metallic nanoparticles in fish}

It has been shown that NPs can be taken up by aquatic organisms and can adversely affect them at the level of algae, invertebrates, and fish (Gaiser et al. 2011; Skjolding et al. 2016). Possible routes of uptake of NPs in fish include absorption through the gill epithelia, the gut epithelia during dietary exposure and drinking, as well as skin epithelia 
(Handy et al. 2008; Nam et al. 2014). From the above mentioned, the skin is thought to have the smallest impact, due to the secretion of protective mucus which can chelate charged NPs, as well as the lack of metal transporters compared to gill (Coello and Khan 1996; Handy et al. 2008). Yue et al. (2016) show endocytic uptake of Ag NPs and their storage in endosomes and lysosomes of cells of RTgill-W1 cell line. Nanoparticle localization was different from $\mathrm{Ag}^{+}$, ions were found predominantly in cytosol, associated with metallothionein-like protein fractions.

The theory of the gut as a viable route of uptake is supported by Gaiser et al. (2011) who exposed common carp for 21 days to nano- and microsized particles of silver and subsequently analyzed silver concentrations in the gills, intestine, blood, liver, gallbladder, kidney, and brain. Significant uptake was detected in the intestine, liver, and gallbladder. Higher concentrations of silver were observed in groups exposed to smaller particles. Chronic dietary intake of ZnO NPs did not cause accumulation of zinc in common carp (Cyprinus carpio) tissues, however, adverse effects on immune system and homeostasis, as well as nephrotoxic and hepatotoxic effects were connected to the $\mathrm{ZnO}$ NPs exposure (Chupani et al. 2017; 2018a). Whether the fish digests food during the exposure plays an important role in the bioavailability and toxicity of ingested substances. Proteins and amino acids have been shown to complexate the $\mathrm{Ag}^{+}$and prevent adverse effects on rainbow trout gut cells (RTGC) in the case of Ag NPs, they were only partially effective in sustaining the metabolic activity and integrity of the cell and lysosomal membranes (Minghetti and Schirmer 2016). It is to be noted that any damage, such as erosion or inflammation of epithelia, disables natural barriers and enables facilitated transport of NPs to the blood circulation and internal organs. The said damage can be caused by the NPs themselves. Chupani et al. (2018b) found an increased rate of apoptosis in the intestinal epithelium as well as increased levels of proteins associated with cancerous cell survival in the muscular layer of the intestine of the common carp (Cyprinus carpio) exposed to a diet containing $\mathrm{ZnO}$ NPs for six weeks.

\section{Trophic transport of metallic nanoparticles}

Bioaccumulation (accumulation of the NPs in the organism) and trophic transport have been shown to occur within the food chain, raising concerns about biomagnification (increased concentration of NPs in the food chain due to predation) within the ecosystems (Nam et al. 2014; Uddin et al. 2020). Ates et al. (2015) reported trophic transport between both $\mathrm{CuO}$ NPs and ZnO NPs contaminated crustacean (Artemia salina) and goldfish (Carassius auratus), resulting in accumulation of both $\mathrm{CuO}$ NPs and ZnO NPs in the intestine, liver, and gills of the goldfish. Similarly, Zhu et al. (2010) proved that $\mathrm{TiO}_{2} \mathrm{NPs}_{\text {can }}$ be transferred from daphnids to zebrafish by dietary exposure, but biomagnification did not occur. On the other hand, Chen et al. (2015) provided the evidence of $\mathrm{TiO}_{2} \mathrm{NPs}$ transfer from an alga (Scenedesmus obliquus) to the water flea (Daphnia magna) with a biomagnification effect. Yoo-iam et al. (2014) evaluated the bioaccumulation and biomagnification of Ag NPs in a model food consisting of green algae (Chlorella spp.), water flea (Moina macrocopa), blood worm (Chironomus spp.), and silver barb (Barbonymus gonionotus). The highest bioaccumulation factor was found in the algae, the lowest bioaccumulation factor was determined in the fish. The trophic transfer occurred only between the algae and the water flea and there was no evidence of biomagnification.

\section{Silver}

Silver NPs are among the most frequently used and researched NPs, thanks to their excellent thermal and electrical conductivity, catalytic properties, nonlinear optical 
properties, as well as antibacterial, antivirotic, antimycotic, antiinflammatory, and anticancer activity (Tian et al. 2007; Nowack et al. 2011; Gurunathan 2015; Shaalan et al. 2016). Silver NPs have a wide range of industrial and consumer applications in the production of electronics, construction, agriculture, food industry, healthcare, and medicine (in both treatment and diagnostics), as well as in household products, appliances, cosmetics, and textiles (Park et al. 2013; European Commission 2014; Geertsma et al. 2015; Zhang et al. 2016). The annual worldwide production of Ag NPs is estimated to be 320 tonnes (Nowack et al. 2011).

Silver ions belong amongst the most toxic metals to fish (Morgan et al. 1997; Hogstrand and Wood 1998), $\mathrm{Ag}^{+}$is attributed to a significant part of the toxic effect of Ag NPs, but not the whole, there is intrinsic toxicity of NPs (Bilberg et al. 2012; Lapresta-Fernández et al. 2012; Khan et al. 2015; Speshock 2018). Van Aerle et al. (2013) applied sequencing-based transcription-profiling on zebrafish embryos exposed to $\mathrm{Ag}$ NPs, bulk silver, and $\mathrm{AgNO}_{3}$ for $48 \mathrm{~h}$. Significant changes in gene expression were found in all exposition groups, with significant overlaps between the groups, particularly pathways associated with oxidative phosphorylation and protein synthesis. Ag NPs specific changes in gene expression were found, suggesting that $\mathrm{Ag}^{+}$is not the only originator of the adverse effect. This claim is supported by a study performed on adult zebrafish exposed to $\mathrm{Ag} \mathrm{NPs}$, and $\mathrm{AgNO}_{3}$ for $48 \mathrm{~h}$. Total silver body burden was significantly higher in groups exposed to Ag NPs and subsequent gene expression analysis revealed a variety of genes, that were differentially expressed only in Ag NPs expositions (Griffitt et al. 2009). The effect of Ag NPs exposition on gills has been studied thoroughly because gills are one of the main spots of $\mathrm{Ag}^{+}$toxicity. Garcia-Reyero et al. (2015) compared the effects of $\mathrm{Ag}$ NPs and $\mathrm{AgNO}_{3}$ on gills of fathead minnow (Pimephales promelas). During the first $4 \mathrm{~h}$, mucus production in all groups increased, which was followed by a decrease in mucus production after $24 \mathrm{~h}$ of exposure. Microarray analysis detected 109 differentially expressed genes shared by both $\mathrm{AgNO}_{3}$ and $\mathrm{Ag}$ NPs, but there as many as 615 differentially expressed genes specific to Ag NPs. In a study by Hawkins et al. (2015), $\mathrm{AgNO}_{3}$ and $\mathrm{Ag}$ NPs caused similar disruptions in gill structure and ionic regulation, including circulatory disturbances, and decreased activity of the $\mathrm{Na}^{+} / \mathrm{K}^{+}$-ATPase.

The developmental toxicity of Ag NPs to fish is well documented (Yeo and Kang 2008; Massarsky et al. 2013; Park et al. 2013; Xia et al. 2016). A dose-dependent increase in mortality, amount of non-hatched embryos, and presence of sublethal malformations, such as the presence of notochord deformations or pericardial oedema, bradycardia, and cardiac arrhythmia were found after $72 \mathrm{~h}$ exposition to Ag NPs. The distribution of Ag NPs was visualized by transmission electron microscopy in the brain, heart, yolk, and blood of the embryos (Asharani et al. 2008). Furthermore, the possibility of transgenerational transfer of silver has been shown in female zebrafish injected with $1 \mathrm{mg} \cdot \cdot^{-1} 10 \mathrm{~nm}$ PVP capped, in which the passage to eggs has been proven. The highest load of Ag NPs was found in the liver of the fish, in which the upregulation of inflammatory gene interleukin-1 $\beta$, tumour necrosis factor alpha (TNF- $\alpha$ ), and pro-apoptotic caspase genes was measured (Speshock et al. 2016).

Impairment of the neurological development, manifesting morphologically as a hypoplastic hindbrain, reduction of the eye and overall head size, plus cardiac defects, accompanied with alteration of the neural development-related genes expression was observed in zebrafish embryos exposed to $\mathrm{Ag} \mathrm{NPs}$ up to $96 \mathrm{~h}$ post fertilization; no free $\mathrm{Ag}^{+}$was detected in exposure solutions. Also, higher accumulation of Ag was observed in the head area of the embryo (Xin et al. 2015). Another study brought evidence of reduction of the acetylcholinesterase (AChE) activity in the brain of adult zebrafish, exposed to $0.1 \mathrm{ppm}$ of Ag NPs for 15 days. This leads to continuous muscle stimulation, manifested in altered responses and behaviour of the fish. Neurological changes were accompanied by necrotic and degenerative changes 
in the liver, as well as decreased activity of liver antioxidant enzymes, catalase, and superoxide dismutase, as a result of oxidative stress (Devi et al. 2015). Induction of oxidative stress was measured in zebrafish liver cells exposed to $120 \mathrm{~nm} \mathrm{Ag} \mathrm{NPs}$ for $24 \mathrm{~h}$. This was accompanied by upregulation of the expression of a variety of endoplasmatic reticulum specific stress marker genes, pro-apoptotic gene Bax, and TNF- $\alpha$. On the other hand, the expression of the tumour suppressor gene p53 was downregulated (Christen et al. 2013). The summary of studies carried out into the toxicity of Ag NPs to fish is listed in Table 1.

\section{Gold}

Gold NPs are popular due to their relatively easy synthesis, stability, catalytic and optoelectronic properties, low toxicity, and high biocompatibility. They are used in technical applications such as electronics, photovoltaics, catalysts, probes, and sensors. Gold NPs also play an important role in medicine, both in diagnostics (for example in tumour detection and imaging) and therapeutic applications - in drug delivery, or as photothermal agents (Chandra et al. 2013; Mahapatra et al. 2015; Patibandla et al. 2018). The estimated worldwide production of Au NPs ranges from 1-3 tonnes per year (Pulit-Prociak and Banach 2016).

Although the toxicity of Au NP is significantly lower than Ag NPs (Bar-Ilan et al. 2009; Lapresta-Fernández et al. 2012; García-Cambero et al. 2013), major adverse effects have been described as well. In a study by Patibandla et al. (2018), exposure of zebrafish embryos to gold nanorods lead to increased mortality, decreased hatching, and a decreased heart rate. A significant increase in the expression of oxidative stress genes as well as increased apoptosis occurred, suggesting an important role of ROS in the mechanism of $\mathrm{Au}$ NPs toxicity.

Similar adverse effect on the circulatory system manifested by the presence of heart oedemas and decreased heart rate was observed in zebrafish embryos exposed to Au NPs stabilized with PVP (Hlavkova et al. 2020). Upregulation of oxidative stress gene expression, as well increased levels of protein biomarkers, such as catalase, superoxide dismutase, and metallothioneins were found in adult zebrafish exposed to $\mathrm{Au}$ NPs for $96 \mathrm{~h}$. Furthermore, decreased swimming speed and abnormalities in the swimming behaviour were observed (Botha et al. 2019). In addition, Dedeh et al. (2014) reported modulation of the expression of genes involved in oxidative stress, mitochondrial metabolism, and DNA repair, as well as altered neurotransmission due to increased brain and muscle AChE activity in adult zebrafish, exposed to Au NPs contaminated sediment for 20 days.

Genotoxic effects of Au NPs have been observed even at concentrations as low as $4 \mu \mathrm{g} \cdot \mathrm{l}^{-1}$ in gilthead seabream (Sparus aurata) exposed to citrate and PVP coated Au NPs for $96 \mathrm{~h}$. Nanoparticles have induced DNA damage (erythrocyte DNA strand breaks), the frequency of erythrocytic nuclear abnormalities was also increased (Barreto et al. 2019). Alteration of gene expression levels, mutations, and mitochondrial dysfunction was observed in zebrafish exposed to citrate capped Au NPs (sized $12 \mathrm{~nm}$ and $50 \mathrm{~nm}$ ) in their diet, over the period of 36 and 60 days. More severe effects were observed in groups fed the smaller particles (Geffroy et al. 2011). The summary of studies carried out into the toxicity of $\mathrm{Au}$ NPs to fish is listed in Table 2.

\section{Titanium dioxide}

Of the group of metal oxides, titanium dioxide is the most commonly used. Piccinno et al. (2012) estimate its annual global production volume to be 3000 tonnes. Titanium dioxide 


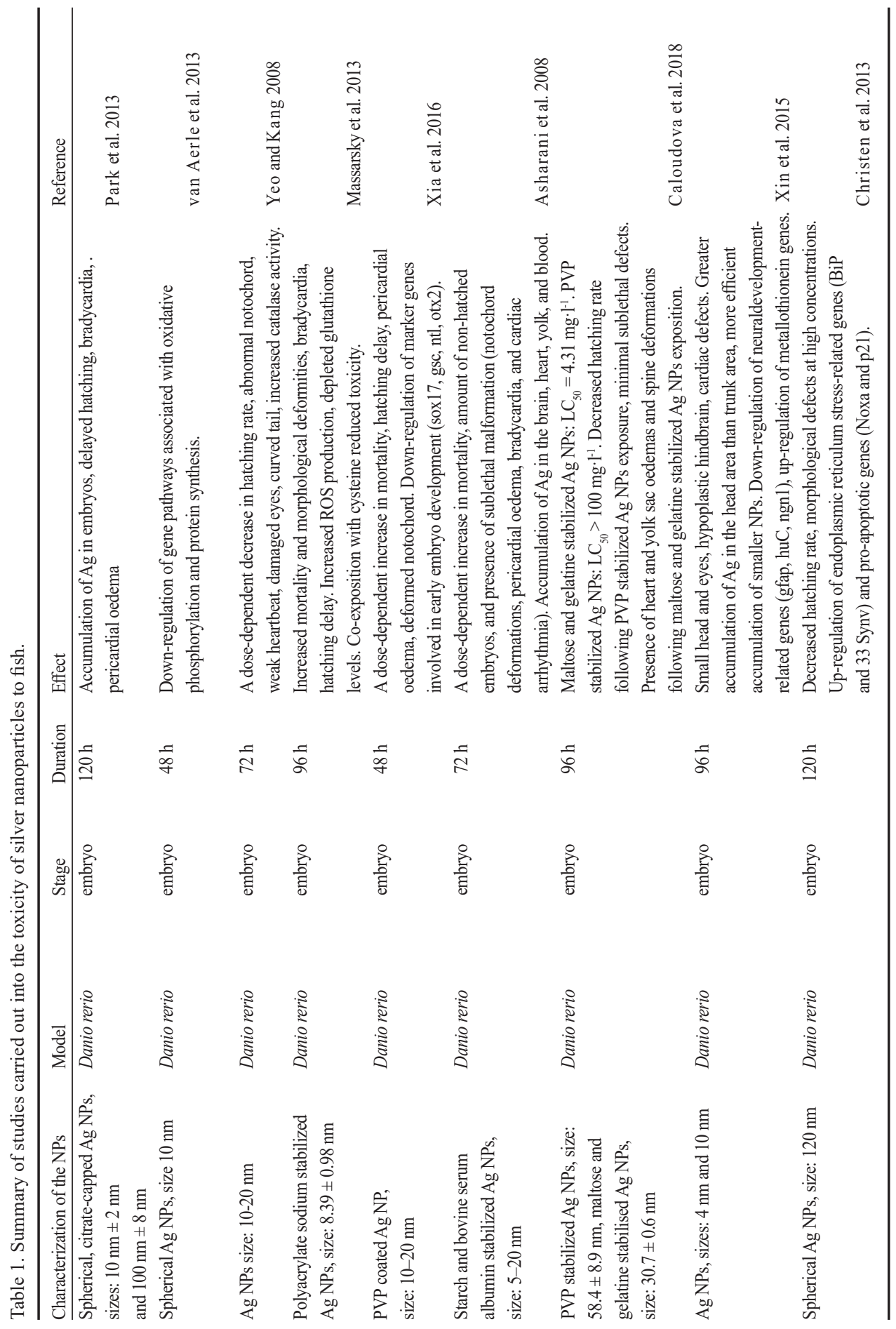




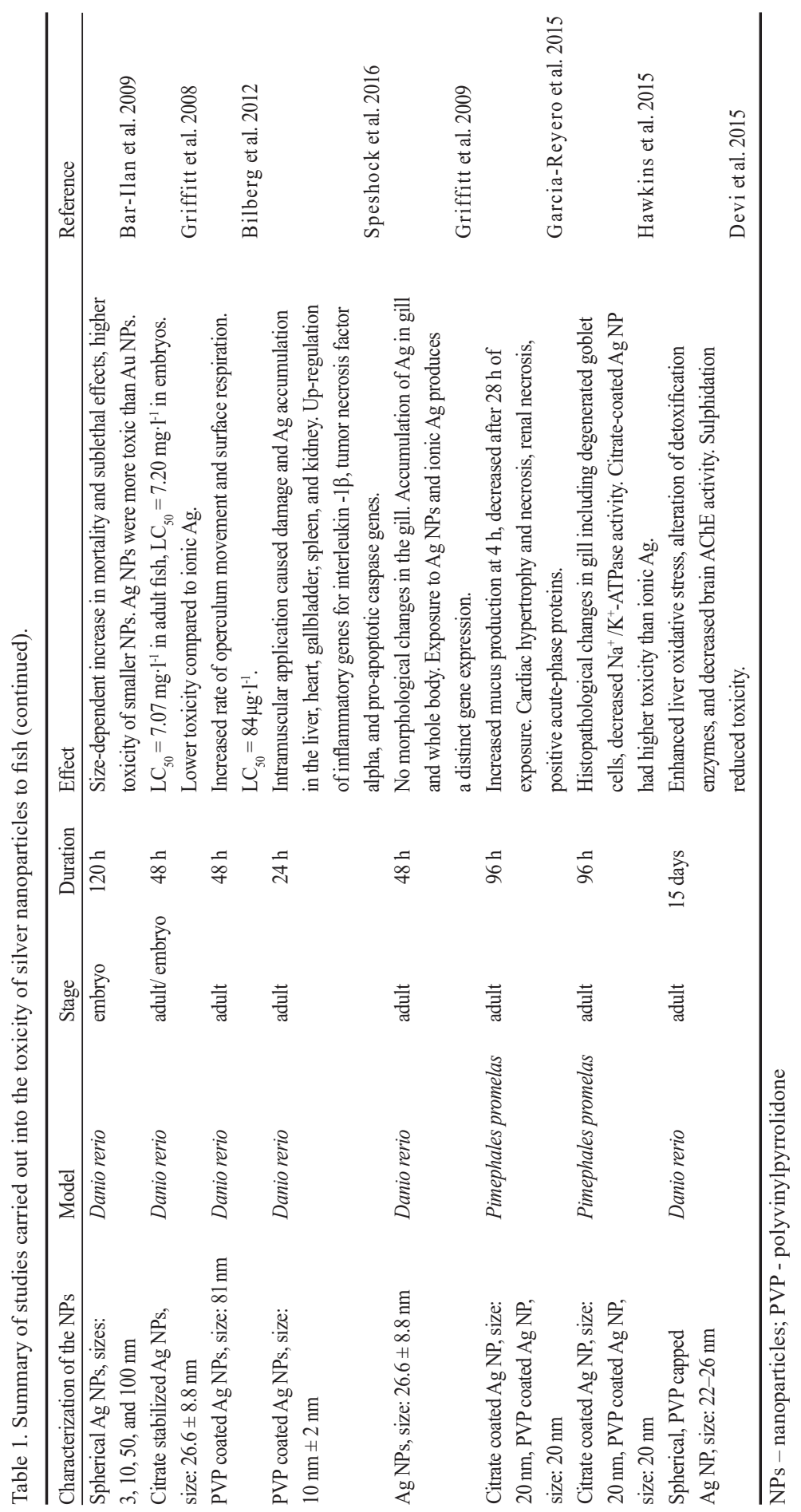




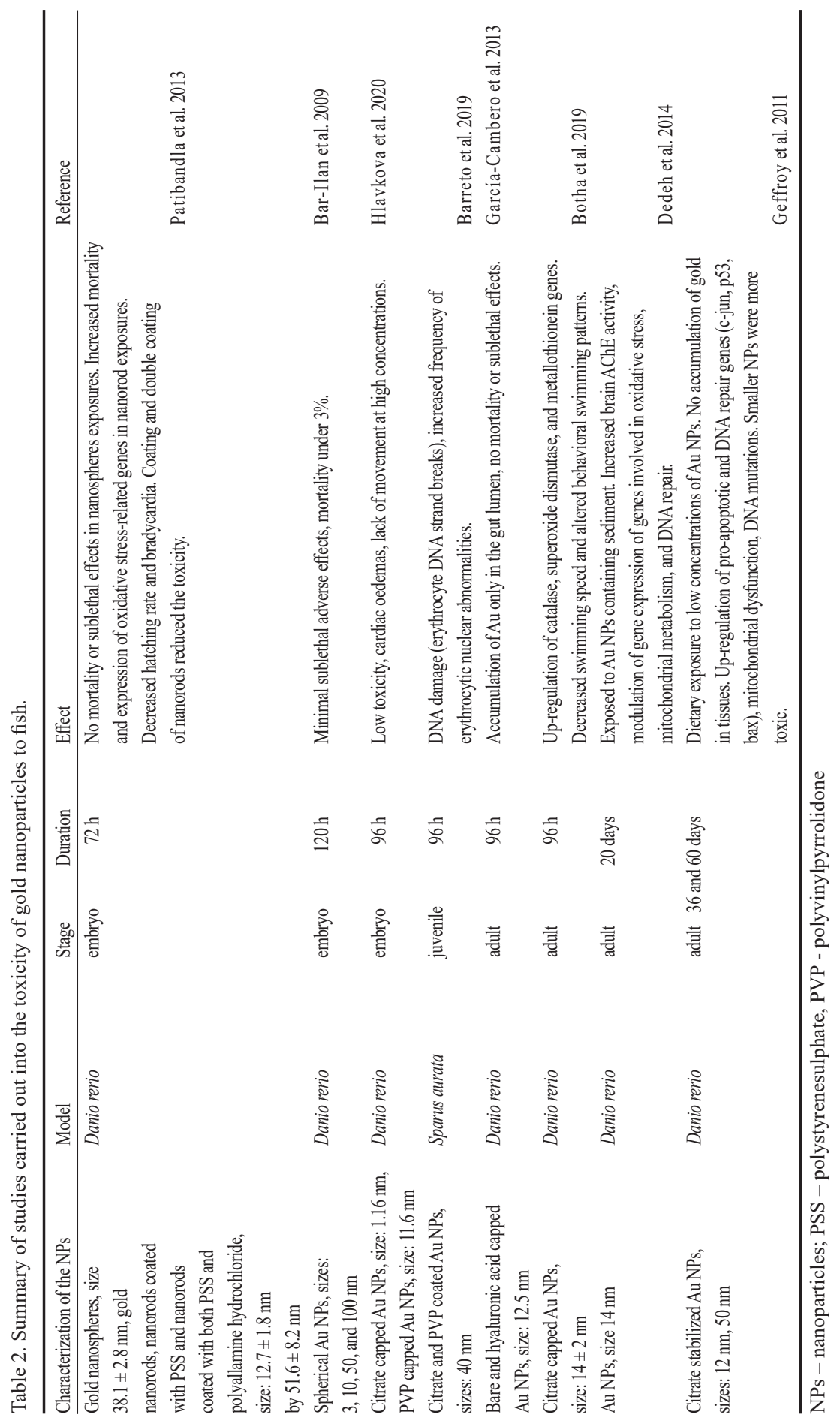


has good electrical properties and catalytic activity, high light reflectance, and a refractive index. It's stable and insoluble in water (Sungur 2020). There are three crystal structures of $\mathrm{TiO}_{2}$, brookite, anatase, and rutile. Anatase is considered to be the most chemically reactive (Shi et al. 2013). $\mathrm{TiO}_{2}$ is used as a photocatalyst in solar panels, in plastics, paints, pharmaceuticals, and even as a food colouring. Since $\mathrm{TiO}_{2}$ is transparent and blocks UV radiation, it is frequently used in cosmetics, especially sunscreens (Klaine et al. 2008; Ray et al. 2009; Stark et al. 2015).

$\mathrm{TiO}_{2}$ is generally thought to be a safe, non-toxic material. Griffitt et al. (2008) performed acute, 48 -h tests with $30 \mathrm{~nm} \mathrm{TiO}, \mathrm{NPs}$ at concentrations of up to $10 \mathrm{mg} \cdot \mathrm{l}^{-1}$ on both adult and larval zebrafish, alongside with adult crustacean Daphnia pulex, juvenile water fleas Ceriodaphnia dubia, and algae (Pseudokirchneriella subcapitata, 96-h test). $\mathrm{TiO}_{2}$ did not cause adverse effects in any of these assays. Similarly, Jemec Kokalj et al. (2019) found no adverse effects on survival, hatching, and sublethal endpoints in zebrafish embryos during an acute 96-h assay, using three anatase $\mathrm{TiO}_{2} \mathrm{NPs}_{\text {(sized } 4.9}$ $\mathrm{nm}, 30 \mathrm{~nm}$, and $5.1 \mathrm{~nm}$ ) and three titania Magnéli suboxides (sized $192 \mathrm{~nm}, 507 \mathrm{~nm}$, and $795 \mathrm{~nm}$ ) at concentrations of up to $100 \mathrm{mg} \cdot \mathrm{l}^{-1}$. Exposure of zebrafish embryos to $\mathrm{TiO}_{2} \mathrm{NPs}$ for $120 \mathrm{~h}$ showed no effect on the survival, hatching, and malformation rates, however, the average and maximum velocity and activity level of the larvae were affected already at $0.1 \mathrm{mg} \cdot \mathrm{l}^{-1}$ (Chen et al. 2011). However, assays with chronic and subchronic duration bring evidence of adverse effects of $\mathrm{TiO}_{2}$, such as reproductive toxicity, namely a $29.5 \%$ loss of eggs, which was found after a 13 -week exposure of zebrafish to $0.1 \mathrm{mg} \cdot \mathrm{l}^{-1}$ anatase $\mathrm{TiO}_{2}$ NPs (Wang et al. 2011). Hepatotoxic effects, likely as an effect of oxidative stress, were found in goldfish (Carassius auratus) and zebrafish exposed to solutions $\mathrm{TiO}_{2} \mathrm{NPs}$ as low as $0.01 \mathrm{mg} \cdot \mathrm{l}^{-1}$ for 21 days, with a subsequent 14 day depuration period. Results of this study show degeneration of hepatocytes and concentration-dependent increase of malondialdehyde, indicating lipid peroxidation and significant glutathione-S-transferase (GST) activity increase at day 7 of exposure, however, at 21 days the GST activity decreased in both species as a result of prolonged stress (Diniz et al. 2013). Similarly, acute ( 2 days) and subchronic (14 days) exposures of juvenile benthic fish Prochilodus lineatus to $\mathrm{TiO}_{2}$ NPs lead to the presence of degenerative alterations of hepatocytes and increase of glutathione after both exposures and GST activity after subchronic exposure. Furthermore, a decrease of the red blood cell count and monocytosis after acute exposure was noted. In the case of subchronic exposure, both red blood cell and white blood cell counts including lymphocytes were decreased, which points to immunotoxic effects of $\mathrm{TiO}_{2}$ NPs (Carmo et al. 2019). This claim is supported by another study, in which fathead minnow was exposed to environmentally relevant concentrations of $\mathrm{TiO}_{2} \mathrm{NPs}$ ( $2 \mathrm{ng} \cdot \mathrm{g}^{-1}$ or $10 \mu \mathrm{g} \cdot \mathrm{g}^{-1}$ of body weight), and subsequently challenged with bacterial

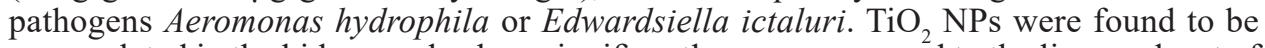
accumulated in the kidney and spleen significantly more compared to the liver and rest of the body, resulting in histopathological damage of these organs. Neutrophil phagocytosis was significantly affected, increased mortality and morbidity during bacterial infection was observed (Jovanović et al. 2015). After subchronic (14 days) semi-static exposure of rainbow trout, histopathological changes in gills (oedema and thickening of the gill lamellae) and erosions of enterocytes, as well as decreased $\mathrm{Na}^{+} / \mathrm{K}^{+}$-ATPase activity in the gills and intestine were observed. Thiobarbituric acid reactive substances (TBARS) were increased in a concentration-dependent manner in the gills, intestine, and brain; the glutathione level was also increased in the gill, suggesting the effect of oxidative stress (Federici et al. 2007). The neurotoxic potential of $\mathrm{TiO}_{2}$ has been shown by the decrease of muscular AChE activity observed in juvenile Prochilodus lineatus in two separate studies (Miranda et al. 2016; Carmo et al. 2019). The summary of studies carried out into the toxicity of $\mathrm{TiO}_{2} \mathrm{NPs}$ to fish is listed in Table 3 . 


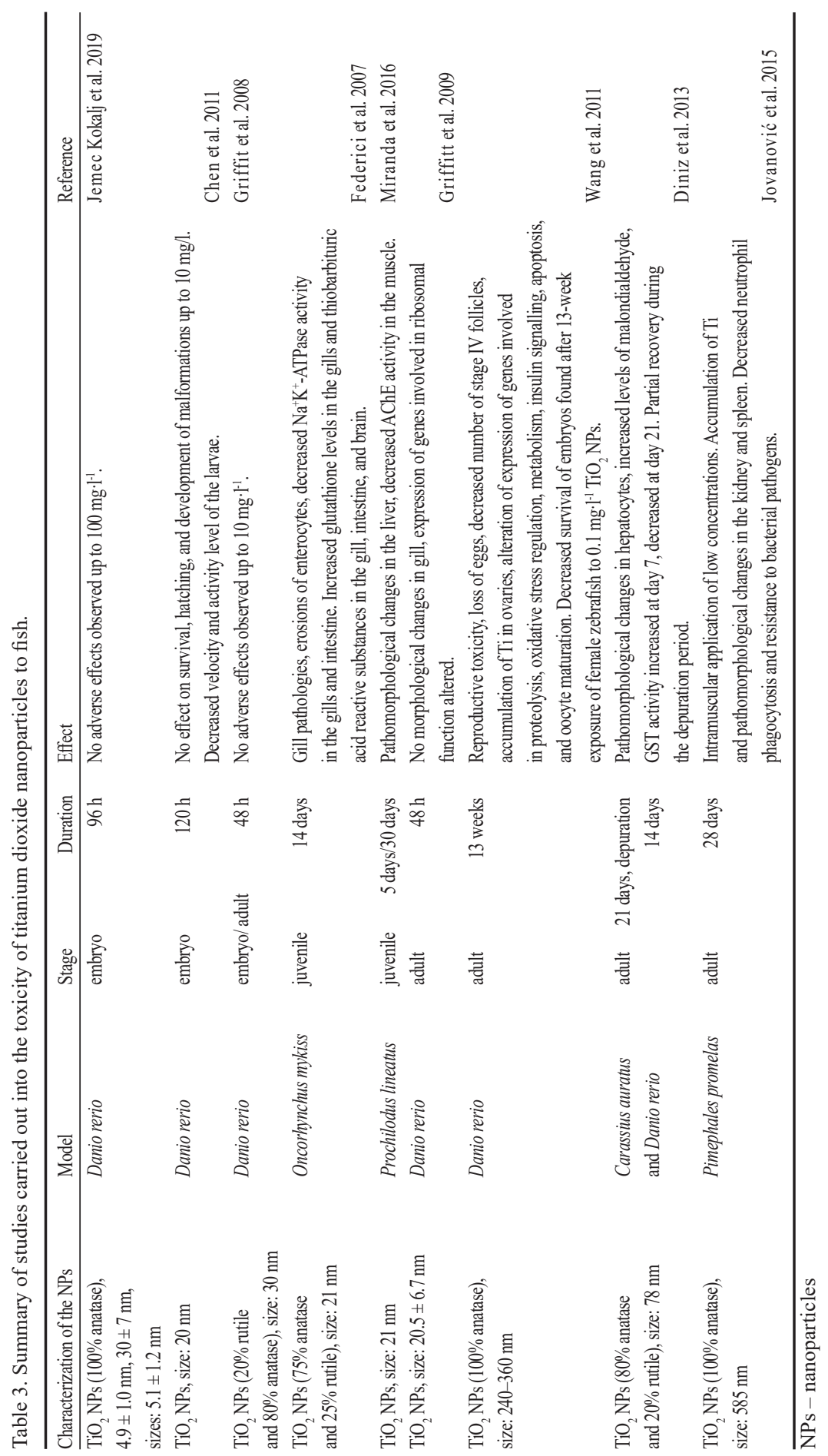




\section{Conclusion}

With the rise of nanotechnology, the importance of thorough nanotoxicological research is growing, because the properties and behaviour of NPs differ from their bulk and ionic counterparts both in vitro and in vivo. A proper characterization of the determining properties of NPs, such as their chemical composition, crystal structure, size, shape, presence of coatings, surface chemistry, charge, and solubility, is a key step of every study. When assessing the overall safety of NPs, an important aspect to consider is the different behaviour of NPs in standardized test media and in the environment, in which NPs interact with the substances present - the natural organic matter and inorganic materials. The toxicity of NPs is thought to be generally lower in the environment than in the laboratory settings, but a cautious approach to nanotechnologies is warranted.

\section{Acknowledgements}

This work was supported by the grant IGA VFU 217/2020/FVHE. The authors thank Mr. Steven Sangsahachart for a language revision of the manuscript.

\section{References}

Angel BM, Batley GE, Jarolimek CV, Rogers NJ 2013: The impact of size on the fate and toxicity of nanoparticulate silver in aquatic systems. Chemosphere 93: 359-365

Asharani PV, Lian Wu Y, Gong Z, Valiyaveettil S 2008: Toxicity of silver nanoparticles in zebrafish models. Nanotechnology 19: 1-7

Ates M, Arslan Z, Demir V, Daniels J, Farah IO 2015: Accumulation and toxicity of CuO and ZnO nanoparticles through waterborne and dietary exposure of goldfish (Carassius auratus). Environ Toxicol 30: 119-128

Azizi-Lalabadi M, Ehsani A, Divband B, Alizadeh-Sani M 2019: Antimicrobial activity of titanium dioxide and zinc oxide nanoparticles supported in 4A zeolite and evaluation the morphological characteristic. Sci Rep 9: 17439

Bar-Ilan O, Albrecht RM, Fako VE, Furgeson DY 2009: Toxicity assessments of multisized gold and silver nanoparticles in zebrafish embryos. Small 5: 1897-1910

Barreto A, Luis LG, Pinto E, Almeida A, Paíga P, Santos LHMLM, Delerue-Matos C, Trindade T, Soares AMVM, Hylland K, Loureiro S, Oliveira M 2019: Genotoxicity of gold nanoparticles in the gilthead seabream (Sparus aurata) after single exposure and combined with the pharmaceutical gemfibrozil. Chemosphere 220: 11-19

Batley GE, Kirby JK, McLaughlin MJ 2013: Fate and risks of nanomaterials in aquatic and terrestrial environments. Acc Chem Res 46: 854-862

Bilberg K, Hovgaard MB, Besenbacher F, Baatrup E 2012: In vivo toxicity of silver nanoparticles and silver ions in zebrafish (Danio rerio). J Toxicol 2012: 1-9

Binnig G, Rohrer H, Gerber C, Weibel E 1982: Surface studies by scanning tunneling microscopy. Phys Rev Lett 49: $57-61$

Botha TL, Brand SJ, Ikenaka Y, Nakayama SMM, Ishizuka M, Wepener V 2019: How toxic is a non-toxic nanomaterial: Behaviour as an indicator of effect in Danio rerio exposed to nanogold. Aquat Toxicol 215: 1-10

Caloudova H, Hodkovicova N, Sehonova P, Blahova J, Marsalek B, Panacek A, Svobodova Z 2018: The effect of silver nanoparticles and silver ions on zebrafish embryos (Danio rerio). Neuro Endocrinol Lett 39: 299-304

Carmo TLL, Siqueira PR, Azevedo VC, Tavares D, Pesenti EC, Cestari MM, Martinez CBR, Fernandes MN 2019: Overview of the toxic effects of titanium dioxide nanoparticles in blood, liver, muscles, and brain of a Neotropical detritivorous fish. Environ Toxicol 34: 457-468

Chandra P, Singh J, Srivastava A, Goyal RN, Shim YB 2013: Gold nanoparticles and nanocomposites in clinical diagnostics using electrochemical methods. J Nanoparticles 2013: 1-12

Chen J, Li H, Han X, Wei X 2015: Transmission and accumulation of nano-TiO, in a 2-step food chain (Scenedesmus obliquus to Daphnia magna). Bull Environ Contam Toxicol 95: 145-149

Chen T-H, Lin C-Y, Tseng M-C 2011: Behavioral effects of titanium dioxide nanoparticles on larval zebrafish (Danio rerio). Mar Pollut Bull 63: 303-308

Christen V, Capelle M, Fent K 2013: Silver nanoparticles induce endoplasmatic reticulum stress response in zebrafish. Toxicol Appl Pharmacol 272: 519-528

Chupani L, Barta J, Zuskova E 2019. Effects of food-borne ZnO nanoparticles on intestinal microbiota of common carp (Cyprinus carpio L.). Environ Sci Pollut Res 26: 25869-25873

Chupani L, Niksirat H, Velíšek J, Stará A, Hradilová Š, Kolařík J, Panáček A, Zusková E 2018a: Chronic dietary toxicity of zinc oxide nanoparticles in common carp (Cyprinus carpio L.): Tissue accumulation and physiological responses. Ecotoxicol Environ Saf 147: 110-116 
Chupani L, Niksirat H, Lünsmann V, Haange SB, Von Bergen M, Jehmlich N, Zuskova E 2018b: Insight into the modulation of intestinal proteome of juvenile common carp (Cyprinus carpio L.) after dietary exposure to $\mathrm{ZnO}$ nanoparticles. Sci Total Environ 613-614: 62-71

Chupani L, Zusková E, Niksirat H, Panáček A, Lünsmann V, Haange S-B, von Bergen M, Jehmlich N 2017: Effects of chronic dietary exposure of zinc oxide nanoparticles on the serum protein profile of juvenile common carp (Cyprinus carpio L.). Sci Total Environ 579: 1504-1511

Clemente Z, Castro VL, Feitosa LO, Lima R, Jonsson CM, Maia AHN, Fraceto LF 2013: Fish exposure to nano- $\mathrm{TiO}_{2}$ under different experimental conditions: Methodological aspects for nanoecotoxicology investigations. Sci Total Environ 463-464: 647-656

Coello WF, Khan MAQ 1996: Protection against heavy metal toxicity by mucus and scales in fish. Arch Environ Contam Toxicol 30: 319-326

Dedeh A, Ciutat A, Treguer-Delapierre M, Bourdineaud J-P 2014: Impact of gold nanoparticles on zebrafish exposed to a spiked sediment. Nanotoxicol 9: 71-80

Deng R, Lin D, Zhu L, Majumdar S, White JC, Gardea-Torresde JL, Xing B 2017: Nanoparticle interactions with co-existing contaminants: joint toxicity, bioaccumulation and risk. Nanotoxicol 11: 591-612

Devi GP, Ahmed KBA, Varsha MKNS, Shrijha BS, Lal KKS, Anbazhagan V, Thiagarajan R 2015: Sulfidation of silver nanoparticle reduces its toxicity in zebrafish. Aquat Toxicol 158: 149-156

Diniz MS, De Matos APA, Lourenço J, Castro L, Peres I, Mendonça E, Picado A 2013: Liver alterations in two freshwater fish species (Carassius auratus and Danio rerio) following exposure to different $\mathrm{TiO}_{2}$ nanoparticle concentrations. Microsc Microanal 19: 1131-1140

European Commission: Opininon on nanosilver: safety, health and environmental effects and role in antimicrobial resistance. Publications Office of the EU. Available at: https://op.europa.eu/en/publication-detail/-/ publication/0dde6746-59a2-419d-91d8-fe2d14a2fec0/language-en. Last modified June 11, 2014. Accessed December 1, 2020

Fard JK, Jafari S, Eghbal MA 2015: A review of molecular mechanisms involved in toxicity of nanoparticles. Adv Pharm Bull 5: 447-454

Federici G, Shaw B, Handy R 2007: Toxicity of titanium dioxide nanoparticles to rainbow trout (Oncorhynchus mykiss): Gill injury, oxidative stress, and other physiological effects. Aquat Toxicol 84: 415-430

Fu PP, Xia Q, Hwang H-M, Ray PC, Yu H 2014: Mechanisms of nanotoxicity: Generation of reactive oxygen species. J Food Drug Anal 22: 64-75

Gaiser BK, Fernandes TF, Jepson MA, Lead JR, Tyler CR, Baalousha M, Biswas A, Britton GJ, Cole PA, Johnston BD, Ju-Nam Y, Rosenkranz P, Scown TM, Stone V 2011: Interspecies comparisons on the uptake and toxicity of silver and cerium dioxide nanoparticles. Environ Toxicol Chem 31: 144-154

García-Cambero JP, Núñez García M, Lopéz GD, Herranz AL, Cuevas L, Pérez-Pastrana E, Cuadal JS, Castelltort MR, Calvo AC 2013: Converging hazard assesment of gold nanoparticles to aquatic organisms. Chemposphere 93: 1194-1200

Garcia-Reyero N, Thornton C, Hawkins AD, Escalon L, Kennedy AJ, Steevens JA, Willett KL 2015: Assessing the exposure to nanosilver and silver nitrate on fathead minnow gill gene expression and mucus production. Environ Nanotechnol Monit Manag 4: 58-66

Geertsma RE, Park MVDZ, Puts CF, Roszek B, Van der Stij1 R, De Jong WH 2015: Nanotechnologies in medical devices. National Institute for Public Health and the Environment, Bilthoven, $83 \mathrm{p}$.

Geffroy B, Ladhar C, Cambier S, Treguer-Delapierre M, Brèthes D, Bourdineaud J-P 2011: Impact of dietary gold nanoparticles in zebrafish at very low contamination pressure: The role of size, concentration and exposure time. Nanotoxicol 6: 144-160

Global Industry Analysts, Inc. 2020: Metal Nanoparticles - Global Market Trajectory \& Analytics. Global Industry Analysts, Inc, Dublin, 187 p.

Gottschalk F, Lassen C, Kjoelholt J, Christensen F, Nowack B 2015: Modeling flows and concentrations of nine engineered nanomaterials in the Danish environment. International Int J Environ Res Public Health 12: 55815602

Gottschalk F, Sonderer T, Scholz RW, Nowack B 2009: Modelled environmental concentrations of engineered nanomaterials ( $\mathrm{TiO}_{2}, \mathrm{ZnO}, \mathrm{Ag}, \mathrm{CNT}$, fullerenes) for different regions. Environ Sci Technol 43: 9216-9222

Grand View Research, Inc. 2020: Nanomaterials Market Size, Share \& Trends Analysis Report By Product (Carbon Nanotubes, Titanium Dioxide), By Application (Medical, Electronics, Paints \& Coatings), By Region, And Segment Forecasts, 2020 - 2027. Grand View Research, Inc., San Francisco, 113 p.

Griffitt RJ, Hyndman K, Denslow ND, Barber DS 2009: Comparison of molecular and histological changes in zebrafish gills exposed to metallic nanoparticles. Toxicol Sci 107: 404-415

Griffitt RJ, Luo J, Gao J, Bonzongo J-C, Barber DS 2008: Effects of particle composition and species on toxicity of metallic nanomaterials in aquatic organisms. Environ Toxicol Chem 27: 1972-1978

Gurunathan S 2015: Biologically synthesized silver nanoparticles enhances antibiotic activity against Gramnegative bacteria. J Ind Eng Chem 29: 217-226

Handy RD, Henry TB, Scown TM, Johnston BD, Tyler CR 2008: Manufactured nanoparticles: their uptake and effects on fish - a mechanistic analysis. Ecotoxicology 17: 396-409

Hawkins AD, Thornton C, Kennedy AJ, Bu K, Cizdziel J, Jones BW, Steevens JA, Willett KL 2015: Gill histopathologies following exposure to nanosilver or silver nitrate. J Toxicol Environ Health A 78: 301-315 
Hlavkova D, Caloudova H, Palikova P, Kopel P, Plhalova L, Beklova M, Havelkova B 2020: Effect of gold nanoparticles and ions exposure on the aquatic organisms. Bull Environ Contam Toxicol 105: 530-537

Hogstrand C, Wood CM 1998: Toward a better understanding of the bioavailability, physiology, and toxicity of silver in fish: Implications for water quality criteria. Environ Toxicol Chem 17: 547-561

Horikoshi S, Serpone N 2013: Microwaves in nanoparticle synthesis: fundamentals and applications. Wiley-VCH Verlag $\mathrm{GmbH}$ and $\mathrm{Co}$, Weinheim, $352 \mathrm{p}$.

Hou WC, Stuart B, Howes R, Zepp RG 2013: Sunlight-driven reduction of silver ions by natural organic matter: formation and transformation of silver nanoparticles. Environ Sci Technol 47: 7713-7721

Hua J, Vijver MG, Richardson MK, Ahmad F, Peijnenburg WJGM 2014: Particle-specific toxic effects of differently shaped zinc oxide nanoparticles to zebrafish embryos (Danio rerio). Environ Toxicol Chem 33: 2859-2868

Impellitteri CA, Harmon S, Silva RG, Miller BW, Scheckel KG, Luxton TP, Schupp D, Panguluri S 2013: Transformation of silver nanoparticles in fresh, aged, and incinerated biosolids. Water Res 47: 3878-3886

International Organization for Standardization 2011: Nanotechnologies-Vocabulary-Part 4: Nanostructured materials. International (ISO Standard 80004-4). ISO copyright office, Geneva, 7 p.

Iswarya V, Manivannan J, De A, Subhabrata P, Rajdeep R, Johnson JB, Kundu R, Chandrasekaran N, Mukherjee A, Mukherjee A 2016: Surface capping and size-dependent toxicity of gold nanoparticles on different trophic levels. Environ Sci Pollut Res 23: 4844-4858

Ivask A, Kurvet I, Kasemets K, Blinova I, Aruoja V, Suppi S, Vija H, Käkinen A, Titma T, Heinlaan M, Visnapuu M, Koller D, Kisand V, Kahru A, Quigg A 2014: Size-dependent toxicity of silver nanoparticles to bacteria, yeast, algae, crustaceans and mammalian cells in vitro. PLoS One 9: 102-108

Jemec Kokalj A, Novak S, Talaber I, Kononenko V, Bizjak Mali L, Vodovnik M, Žegura B, Eleršek T, Kalčikova G, Žgajnar Gotvajn A, Kralj S, Makovec D, Caloudova H, Drobne D 2019: The first comprehensive safety study of Magnéli phase titanium suboxides reveals no acute environmental hazard. Environ SciNano 6: $1131-1139$

Jovanović B, Whitley EM, Kimura K, Crumpton A, Palić D 2015: Titanium dioxide nanoparticles enhance mortality of fish exposed to bacterial pathogens. Environ Pollut 203: 153-164

Kaegi R, Voegelin A, Ort C 2013: Fate and transformation of silver nanoparticles in urban wastewater systems. Water Res 47: 3866-3877

Khan MS, Jabeen F, Qureshi NA, Asghar MS, Shakeel M, Noureen A 2015: Toxicity of silver nanoparticles in fish: a critical review. JBES 6: 211-227

Khanna P, Kaur A, Goyal D 2019: Algae-based metallic nanoparticles: Synthesis, characterization and applications. J Microbiol Methods. 163: 105656

Khot LR, Sankaran S, Maja JM, Ehsani R, Schuster EW 2012: Applications of nanomaterials in agricultural production and crop protection: A review. J Crop Prot 35: 64-70

Klaine SJ, Alvarez PJJ, Batley GE, Fernandes TF, Handy RD, Lyon DY, Mahendra S, McLaughlin MJ, Lead JR 2008: Nanomaterials in the environment: Behavior, fate, bioavailability, and effects. Environ Toxicol Chem 27: $1825-1851$

Kováŕík L, Dvořák P, Beňová K, Doležalová J, Tomko M, Špalková M 2020: Interaction of radionuclide 131I and cadmium chloride in an alternative bioassay with Artemia franciscana evaluated by a digital record. Acta Vet Brno 89: 413-420

Kwak JI, An YJ 2016: The current state of the art in research on engineered nanomaterials and terrestrial environments: Different-scale approaches. Environ Res 151: 368-382

Lapresta-Fernández A, Fernández A, Blasco J 2012: Nanoecotoxicity effects of engineered silver and gold nanoparticles in aquatic organisms. Trends Analyt Chem 32: 40-59

Lee KJ, Nallathamby PD, Browning LM, Osgood CJ, Xu X-HN 2007: In vivo imaging of transport and biocompatibility of single silver nanoparticles in early development of zebrafish embryos. ACS Nano 1: $133-143$

Li L, Sillanpää M, Risto M 2016: Influences of water properties on the aggregation and deposition of engineered titanium dioxide nanoparticles in natural waters. Environ Pollut 219: 132-138

Liu Y, Majetich SA, Tilton RD, Sholl DS, Lowry GV 2005: TCE dechlorination rates, pathways, and efficiency of nanoscale iron particles with different properties. Environ Sci Technol 39: 1338-1345

Ma S, Lin D 2013: The biophysicochemical interactions at the interfaces between nanoparticles and aquatic organisms: adsorption and internalization. Environ Sci Processes Impacts 15: 145-160

Mahapatra I, Sun TY, Clark JRA, Dobson PJ, Hungerbuehler K, Owen R, Nowack B, Lead J 2015: Probabilistic modelling of prospective environmental concentrations of gold nanoparticles from medical applications as a basis for risk assessment. J Nanobiotechnology 13: 1-14

Manke A, Wang L, Rojanasakul Y 2013: Mechanisms of nanoparticle-induced oxidative stress and toxicity. BioMed Res Int 2013: 1-15

Massarsky A, Dupuis L, Taylor J, Eisa-Beygi S, Strek L, Trudeau VL, Moon TW 2013: Assessment of nanosilver toxicity during zebrafish (Danio rerio) development. Chemosphere 92: 59-66

Minghetti M, Schirmer K 2016: Effect of media composition on bioavailability and toxicity of silver and silver nanoparticles in fish intestinal cells (RTgutGC). Nanotoxicol 10: 1526-1534 
Miranda RR, Damaso da Silveira ALR, de Jesus IP, Grötzner SR, Voigt CL, Campos SX, Garcia JRE, Randi MAF, de Oliveira Ribeiro CA, Filipak Neto F 2016: Effects of realistic concentrations of $\mathrm{TiO}_{2}$ and $\mathrm{ZnO}$ nanoparticles in Prochilodus lineatus juvenile fish. Environ Sci Pollut Res 23: 5179-5188

Monteiro-Riviere NA, Tran CL 2007: Nanotoxicology characterization, dosing and health effects. Informa Healthcare, New York, $425 \mathrm{p}$.

Morgan IJ, Henry RP, Wood CM 1997: The mechanism of acute silver nitrate toxicity in freshwater rainbow trout (Oncorhynchus mykiss) is inhibition of gill $\mathrm{Na}^{+}$and $\mathrm{Cl}^{-1}$ transport. Aquat Toxicol 38: 145-163

Nam D-H, Lee, B-C, Eom I-C, Kim P, Yeo M-K 2014: Uptake and bioaccumulation of titanium - and silvernanoparticles in aquatic ecosystems. Mol Cell Toxicol 10: 9-17

Nel A, Xia T, Mädler N, Li N 2006: Toxic potential of materials at the nanolevel. Science 311: 622-627

Nowack B, Krug HF, Height M 2011: 120 Years of nanosilver history: Implications for policy makers. Environ Sci Technol 45: 1177-1183

Pamies R, Cifre JGH, Espín VF, Collado-González M, Baños FGD, de la Torre JG 2014: Aggregation behaviour of gold nanoparticles in saline aqueous media. J Nanopart Res, 16: 2376

Park K, Tuttle G, Sinche F, Harper SL 2013: Stability of citrate-capped silver nanoparticles in exposure media and their effects on the development of embryonic zebrafish (Danio rerio). Arch Pharm Res 36: 125-133

Patibandla S, Zhang Y, Tohari AM, Gu P, Reilly J, Chen Y, Shu X 2018: Comparative analysis of the toxicity of gold nanoparticles in zebrafish. J Appl Toxicol 38: 1153-1162

Peters RJB, van Bemmel G, Milani NBL, den Hertog GCT, Undas AK, van der Lee M, Bouwmeester H 2018 : Detection of nanoparticles in Dutch surface waters. Sci Total Environ 621: 210-218

Piccinno F, Gottschalk F, Seeger S, Nowack B 2012: Industrial production quantities and uses of ten engineered nanomaterials in Europe and the world. J Nanopart Res 14: 1109-1120

Pulit-Prociak J, Banach M 2016: Silver nanoparticles - a material of the future...? Open Chem J 14: 76-91

Ray PC, Yu H, Fu PP 2009: Toxicity and environmental risks of nanomaterials: Challenges and future needs. J Environ Sci Health, Part C 27: 1-35

Ribeiro F, Gallego-Urrea JA, Jurkschat K, Crossley A, Hassellöv M, Taylor C, Soares AMVM, Loureiro S 2014: Silver nanoparticles and silver nitrate induce high toxicity to Pseudokirchneriella subcapitata, Daphnia magna and Danio rerio. Sci Total Environ 466-467: 232-241

Sevcikova M, Modra H, Slaninova A, Svobodova Z 2011: Metals as a cause of oxidative stress in fish: a review. Vet Med 56: 537-546

Shaalan M, Saleh M, El-Mahdy M, El-Matbouli M 2016: Recent progress in applications of nanoparticles in fish medicine: A review. Nanomedicine 12: 701-710

Schaumann GE, Philippe A, Bundschuh M, Metreveli G, Klitzke S, Rakcheev D, Grün A, Kumahor SK, Kühn M, Baumann T, Lang F, Manz W, Schulz R, Vogel H-J 2015: Understanding the fate and biological effects

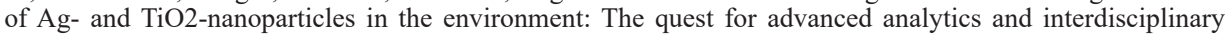
concepts. Sci Total Environ 535: 3-19.

Sharma R, Garg R, Kumari A 2020: A review on biogenic synthesis, applications and toxicity aspects of zinc oxide nanoparticles. EXCLI J 19: 1325-1340

Shi H, Magaye R, Castranova V, Zhao J 2013: Titanium dioxide nanoparticles: a review of current toxicological data. Part Fibre Toxicol 10: 15-48

Shih YJ, Su CC, Chen CW, Dong CD, Liu WS, Huang CP 2016: Adsorption characteristics of nano-TiO ${ }_{2}$ onto zebrafish embryos and its impacts on egg hatching. Chemosphere 154: 109-117

Skjolding LM, Sørensen SN, Hartmann NB, Hjorth R, Hansen SF, Baun A 2016: Aquatic ecotoxicity testing of nanoparticles - The quest to disclose nanoparticle effects. Angew Chem 55: 15224-15239

Speshock JL, Elrod N, Sadoski DK, Maurer E, Braydich-Stolle LK, Brady J, Hussain S 2016: Differential organ toxicity in the adult zebra fish following exposure to acute sub-lethal doses of $10 \mathrm{~nm}$ silver nanoparticles. Front Nanosci Nanotech 2: 114-120

Speshock JL 2018: Review of the toxicological effects of silver nanomaterials on the model aquatic organism Danio rerio. Front Nanosci Nanotech 4: 1-4

Stark WJ, Stoessel PR, Wohlleben W, Hafner A 2015: Industrial applications of nanoparticles. Chem Soc Rev 44: 5793-5805

Sun TY, Gottschalk F, Hungerbühler K, Nowack B 2014: Comprehensive probabilistic modelling of environmental emissions of engineered nanomaterials. Environ Pollut 185: 69-76

Sun, TY, Bornhöft NA, Hungerbühler K, Nowack B 2016: Dynamic probabilistic modeling of environmental emissions of engineered nanomaterials. Environ Sci Technol 50: 4701-4711

Sungur Ş 2020: Titanium Dioxide Nanoparticles. In: Kharissova O, Martínez L, Kharisov B (Ed.): Handbook of nanomaterials and nanocomposites for energy and environmental applications. Springer Cham, Switzerland, pp. 1-18

Svoboda M, Drápal J, Haruštiaková D, Svobodová Z 2020: A multiannual survey of cadmium content in pig tissues collected in the Czech Republic during the years 2015-2019. Acta Vet Brno 89: 349-355

Tian J, Wong KKY, Ho C-M, Lok C-N, Yu W-Y, Che C-M, Chiu J-F, Tam PKH 2007: Topical delivery of silver nanoparticles promotes wound healing. Chem Med Chem 2: 129-136

Uddin MN, Desai F, Asmatulu E 2020: Engineered nanomaterials in the environment: bioaccumulation, biomagnification and biotransformation. Environ Chem Lett 18: 1073-1083 
Ulrich K, Jakob U 2019: The role of thiols in antioxidant systems. Free Radic Biol Med 140: 14-27

Valério A, Sárria MP, Rodriguez-Lorenzo L, Hotza D, Espiña B, Gómez González SY 2020: Are TiO 2 nanoparticles safe for photocatalysis in aqueous media? Nanoscale Adv 2: 4951-4960

Van Aerle R, Lange A, Moorhouse A, Paszkiewicz K, Ball K, Johnston BD, De-Bastos E, Booth T, Tyler CR, Santos EM 2013: Molecular mechanisms of toxicity of silver nanoparticles in zebrafish embryos. Environ Sci Technol 47: 8005-8014

Wang J, Zhu X, Zhang X, Zhao Z, Liu H, George R, Wilson-Rawls J, Chang Y, Chen, Y 2011: Disruption of zebrafish (Danio rerio) reproduction upon chronic exposure to $\mathrm{TiO}_{2}$ nanoparticles. Chemosphere 83: 461-467

Warheit DB 2008: How meaningful are the results of nanotoxicity studies in the absence of adequate material characterization? Toxicol Sci 101: 183-185

Wijnhoven SWP, Peijnenburg WJGM, Herberts CA, Hagens WI, Oomen AG, Heugens EHW, Roszek B, Bisschops J, Gosens I, Van De Meent D, Dekkers S, De Jong WH, Van Zijverden M, Sips AJAM, Geertsma RE 2009: Nano-silver - a review of available data and knowledge gaps in human and environmental risk assessment. Nanotoxicol 3: 109-138

Xia G, Liu T, Wang Z, Hou Y, Dong L, Zhu J, Qi J 2016: The effect of silver nanoparticles on zebrafish embryonic development and toxicology. Artif Cells Nanomed Biotechnol 44: 1116-1121

Xin Q, Rotchell JM, Cheng J, Yi J, Zhang Q 2015: Silver nanoparticles affect the neural development of zebrafish embryos. J Appl Toxicol 35: 1481-1492

Yaqoob AA, Ahmad H, Parveen T, Ahmad A, Oves M, Ismail IMI, Quari HA, Umar K, Mohamad IMN 2020: Recent advances in metal decorated nanomaterials and their various biological applications: A review. Front Chem 8: 341

Yeo M-K, Kang M 2008: Effects of nanometer sized silver materials on biological toxicity during zebrafish embryogenesis. Bull Korean Chem Soc 29: 1179-1184

Yoo-iam M, Chaichana R, Satapanajaru T 2014: Toxicity, bioaccumulation and biomagnification of silver nanoparticles in green algae (Chlorella sp.), water flea (Moina macrocopa), blood worm (Chironomus spp.) and silver barb (Barbonymus gonionotus). Chem Speciat Bioavailab 26: 257-265

Yue Y, Behra R, Sigg L, Suter M J-F, Pillai S, Schirmer K 2016: Silver nanoparticle - protein interactions in intact rainbow trout gill cells. Environ Sci Nano 3: 1174-1185

Zhang X-F, Liu Z-G, Shen W, Gurunathan S 2016: Silver nanoparticles: Synthesis, characterization, properties, applications, and therapeutic approaches. Int J Mol Sci 17: 1534

Zhou M, Wang B, Rozynek Z, Xie Z, Fossum JO, Yu X, Raaen S 2009: Minute synthesis of extremely stable gold nanoparticles. Nanotechnology 20: 1-10

Zhu X, Wang J, Zhang X, Chang Y, Chen Y 2010: Trophic transfer of $\mathrm{TiO}_{2}$ nanoparticles from daphnia to zebrafish in a simplified freshwater food chain. Chemosphere 79: 928-933

Zhu XS, Zhou J, Cai ZH 2011: $\mathrm{TiO}_{2}$ nanoparticles in the marine environment: Impact on the toxicity of tributyltin to abalone (Haliotis diversicolor supertexta) embryos. Environ Sci Technol 45: 3753-3758 